\title{
Decadal oscillations of the aquatic chemistry of river waters in Latvia
}

\author{
Dmitry Porshnov and Maris Klavins \\ Faculty of Geography and Earth Sciences, University of Latvia, Riga, Latvia \\ Correspondence to: Dmitry Porshnov (dmitrijs.porsnovs@lu.lv) \\ Published: 17 October 2016
}

\begin{abstract}
Water quality changes of surface waters can be used to assess human impact intensity, but of importance is to consider also impacts of climate change/variability and naturally occurring changes of environmental quality. In Latvia, during the recent decades a major reduction of anthropogenic pressure has happened due to restructuring of economy and industrial production, resulting in major decrease of loading of many groups of pollutants. However, trends and driving factors for other groups of substances have not been much studied. Long term (1980-2012) results of hydrochemical monitoring, performed in rivers of Latvia, are analysed during this study in connection with long-term sets of hydrological and heliophysical data, using standard statistical approaches. Our results indicate that variation of some hydrochemical values, for example COD and total Fe, show clearly visible decadal oscillated character, while variation of some other values, for example phosphate $\mathrm{P}$ and total $\mathrm{P}$, show some individual characteristics of decadal oscillations. These results indicate the presence of a large scale, geochemical and geophysical significant process: multiannual pulse of catchment, driven by variation of solar irradiance through complex interactions between global atmospheric circulation, groundwater and surface waterbodies. The process described in our study is significant from a geochemical point of view and must be taken into account in prediction of water quality and quantity. Impacts of natural processes should be considered in the planning of environmental policy.
\end{abstract}

\section{Introduction}

The runoff of dissolved substances by riverine waters is an important factor in evaluation of not only water quality, but more important, of the character of the processes in waterbody basins (Henriksen et al., 1998). Rivers act as conveyers transporting dissolved substances from continents to seas. Thus, the integral dimensions of adverse processes in water body basins and the increased geochemical mobility of water ingredients can be identified by studying surface-waterdriven geochemical flows (Stumm and Morgan, 1996). Increased flows of dissolved substances can affect the living environment of aquatic biota, especially in the receiving water bodies, such as the Gulf of Riga and the Baltic Sea, in the case of Latvia.

Chemical composition of surface waters is determined by numerous factors and it depends, at first, on natural conditions (physico-geographical character of the region, climate, hydrology, hydrogeology etc.), but also on the level and ex- tent of human impact. Considering many different sources of water ingredients, the study of their contribution to the aquatic chemistry is at utmost importance in evaluation of water quality (Hounslow, 1995). Studies of aquatic chemistry have also been used to reveal the dimension of the human activity-related processes in water body basins which have changed water composition (both at global, regional and local level), to mention industrial production (wastewater and solid waste dumping) and agricultural activities (non-point pollution sources), as well as impacts of hydro-technical constructions and changes of land-use patterns. Also, impacts of climate change of water composition and flows of substances might be considered as major actuality (Whitehead et al., 2009).

Commonly, temporal changes of geochemical flows of dissolved substances, have been done in terms of linear trend analysis, even though the character of variance of these flows can be much more complex (Libiseller and Grimvall, 
2002). At the same time river discharge regimes, surface water composition and flows of dissolved substances have not only linear trend of changes, but well expressed periodicity (Pekarova et al., 2003). Oscillations of the discharge intensity, with main frequency of about 20 and 13 years in rivers of Latvia, were reported by Klavins et al. (2002a). Periodic oscillations of groundwater levels and levels of deeper underground aquifers in Latvia, with a main frequency of about 11 years, were reported by Levina et al. (1995). So, it is very credible, that similar oscillational patterns are characteristic also for fluxes of dissolved substances with riverine waters.

The results for the 35-year-period of systematic observations of the concentrations of analysed substances allow estimating more or less credible values of flows of these substances in river waters. The aim of this study is to investigate the oscillation patterns in the temporal variation of flows of dissolved substances in surface waters in Latvia.

\section{Physio-geographical characteristics of the study area}

Latvia is a country situated on the eastern coast of the Baltic Sea in North Eastern Europe. Chemical composition of surface waters of Latvia is influenced by geographical, geological, and geochemical processes. At first, possible impacts on geographical factors should be mentioned: the surface is characterised by flat surface topography (57\% of Latvia's territory is located below $100 \mathrm{~m}$ above the sea level, and only $2.5 \%$ of the area reaches $200 \mathrm{~m}$ ). The surficial geology has been formed by Quaternary glacial and ancient sea sediments and by recent exogenous processes. The most widely distributed parent soil materials are moraine loam and sands which are resistant to weathering processes. More than one half of Latvian soils are humic podsols with comparatively high content of organic matter (Klavins et al., 2002b). Latvia has a comparatively dense network of rivers. The climatic conditions of Latvia are dominated by transport of cyclonic air masses from the Atlantic Ocean, leading to comparatively high humidity, uneven distribution of atmospheric precipitation through the year, mild winters and moist summers (Klavins et al., 2003). The study area covered the major river basins of Latvia (Lielupe and Daugava) which supply the dominant part of the water runoff $\left(24 \mathrm{~km}^{3}\right.$ or $69 \%$ of the total runoff).

Daugava, also known as Western Dvina is the largest river of Latvia and also one of the biggest rivers in the Baltic region. It is $1005 \mathrm{~km}$ long and its basin size is $87900 \mathrm{~km}^{2}$, including territories of Latvia, Belorussia and Russia. Mean water runoff in Daugava constitutes $20,4 \mathrm{~km}^{3}$. The mean precipitation ranges from 600 to $900 \mathrm{~mm}$ per year (Statistical Yearbook of Latvia, 1997). More than half of the river discharge takes place during spring floods, and the water discharge pattern is characterised by steep fluctuations of water discharge intensity. Characteristic soil bedrocks in Dau- gava basin are quaternary sand, loam and sandy loam of glacial origin. Podzolic soils, stagnosols and peat soils are widely distributed. The area covered by forests (mostly boreal) is $37800 \mathrm{~km}^{2}(43 \%)$, and bog area about $4400 \mathrm{~km}^{2}$ (5\%). Depth of groundwater active exchange zone is 200 $350 \mathrm{~m}$, aeration zone, mostly consisted of sand and is 1$15 \mathrm{~m}$ deep. In the previous studies, a 26-year periodicity of the flow of the Daugava River was considered as the main period, which includes smaller cycles of 2, 6 and 13 years (Glazacheva, 1988).

Lielupe is the second biggest river of Latvia, with strongly different catchment characteristics. Length of Lielupe is $119 \mathrm{~km}$, basin area $17600 \mathrm{~km}^{2}$, mean annual runoff $3.6 \mathrm{~km}^{3}$. Annual precipitation amounts in Lielupe basin are lower than average in Latvia $(500-700 \mathrm{~mm})$, due to dominantly downward direction of air mases in this region (Anonymous, 2009). Lielupe receives the major part of its discharge from direct surface run-off, spring floods dominate, and the role of permanent water discharge during the year is comparatively low $(\sim 40 \%)$ (Klavins et al., 2003). The geological structure of the catchment is characterised by several meters of thin layer of quaternary deposits (mainly limnoglacial clay). Underlying Devonian deposits, mainly dolomite, limestone, sandstone and clay embed very close to surface and often expose in river valleys. Sod alkaline soils and brown soils on clay and sand bedrock are characteristic of this area, stagnasols and podzols also are prevalent (Anonymous, 2009). Bog areas (3\%) are present in Lielupe catchment, but they are situated downstream from monitoring point used for this study, therefore impacts of wetlands on geochemical fluxes from Lielupe catchment are not taken into account. Soils of Lielupe catchment are fertile and valuable for agriculture, so agricultural areas are widely distributed here and take $71 \%$ of total catchment area, forest areas (mostly nemoral) are limited and cover only $22 \%$ of area (Anonymous, 2009).

\section{Materials and methods}

Hydrochemical and hydrological data used in this study were collected by the Centre for Geology, Hydrometeorology and Environment within the National monitoring program. Monthly records of river discharge from gauging stations on Daugava (Jēkabpils) and Lielupe (Kalnciems) were used. Sampling and analytical methods followed the standard methods during all the study period (Tsirkunov et al., 1992). From 1980 till 1993, water ingredients were analysed according to standard methods used in USSR, as summarised in Standard Methods (1973). After 1993 standard methods described in APHA (1992) were used. During 19921994, inter-calibration programmes, both at national and international levels, have demonstrated general acceptability of the used methods (Stålnacke, 1996). Average concentrations of chemical substances (Fetot, TOC, COD, ${\mathrm{P}-\mathrm{PO}_{4}, \mathrm{~N}-}^{-}$ $\mathrm{NH}_{3}$ and $\mathrm{N}-\mathrm{NO}_{3}$ ) in rivers were calculated using the data 


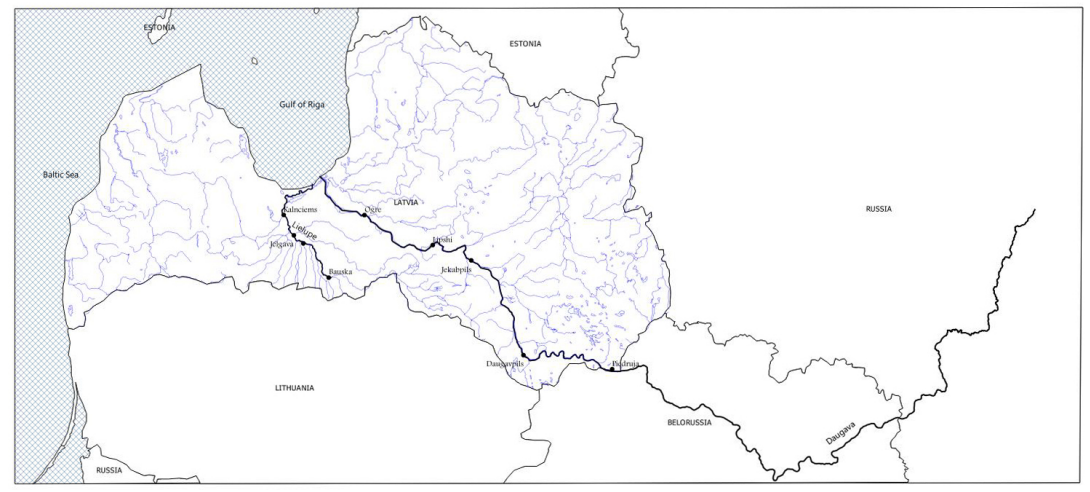

Figure 1. Monitoring points under analysis.

obtained at the following sampling stations: Piedruja, Daugavpils, Jekabpils, Lipshi and Ogre on the Daugava River and Bauska, Jelgava 1, Jelgava 2 and Kalnciems on the Lielupe River (Fig. 1). The used Total Solar Irradiance (TSI) data (2015) was obtained by the VIRGO project as described by Frohlich (2006). All the data under analysis was recalculated, using 24 month moving average function. Microsoft Excel was employed for data management and the construction of curves. NIWA Time Trends software was taken for linear trend analysis by Mann Kendall test, as described by Hirsh and Slack (1984), as well as for linear regression analysis.

Flux of total iron and nutrients were estimated, with the help of available raw monitoring data, while flux of organic matter, taking into account limits of data availability, was evaluated using COD values for the period 1980-2003 and TOC values for the period 2003-2012. TOC values for the first 23 years of study were calculated from COD concentrations using formula proposed by Klavins et al. (2012).

$\mathrm{TOC}=(0.2928 \times \mathrm{COD})+7.9503$

The export of substances was determined as:

$R=W c$

where $W$ - volume of the water flow per day in a specific period $\mathrm{m}^{3},\left(\mathrm{~km}^{3}\right) ; c$ - average concentration of a substance in this period in river waters, $\mathrm{mg} \mathrm{L}^{-1}\left(\mathrm{~g} \mathrm{~m}^{-3}\right)$. The result values were recalculated as tons per day $(24 \mathrm{~h})$. Descriptive characteristics of the obtained data sets are described in Table 1.

\section{Results and discussion}

As it can be seen in Fig. 2, the character of the variation of discharge values in the studied rivers obviously can be described as oscillated. Signs of oscillations with 20, 11, 8-9, 3-5 and 2 years long periods can be observed, that generally corresponds to the results of earlier studies (Glazacheva, 1988; Klavins et al., 2002a). Increase of water color, known also as brownification, was frequently reported in many lakes
Table 1. Descriptive characteristics of data sets under analysis.

\begin{tabular}{lrrrrrr}
\hline Daugava & TOC & $\mathrm{Fe}$ Tot & $\mathrm{N}^{-\mathrm{NO}_{3}}$ & $\mathrm{~N}^{-N_{4}}$ & $\mathrm{P}^{-} \mathrm{PO}_{4}$ & Color \\
\hline Sample size & 311 & 250 & 369 & 368 & 370 & 199 \\
Min. & 103.7 & 0.16 & 0.06 & 0.13 & 0.1 & 16 \\
Max. & 5190.3 & 71 & 336 & 56.4 & 12 & 300 \\
Mean & 937.1 & 12.7 & 41.6 & 5.3 & 1.9 & 85.6 \\
Median & 650.6 & 7.6 & 26.8 & 3.9 & 1.5 & 83 \\
Stand. dev. & 826.6 & 13.7 & 45.1 & 5.7 & 1.65 & 38 \\
\hline Lielupe & $\mathrm{TOC}$ & $\mathrm{Fe} \mathrm{Tot}$ & $\mathrm{N}^{-\mathrm{NO}_{3}}$ & $\mathrm{~N}^{-\mathrm{NH}_{4}}$ & $\mathrm{P}^{-\mathrm{PO}_{4}}$ & Color \\
\hline Sample size & 342 & 274 & 353 & 354 & 362 & 313 \\
Min. & 12.9 & 0.1 & 0.02 & 0.03 & 0.01 & 14 \\
Max. & 1091.2 & 2.0 & 307 & 21.2 & 9.1 & 521 \\
Mean & 161.5 & 0.7 & 29.1 & 1.6 & 0.6 & 82.8 \\
Median & 93.6 & 0.6 & 9.5 & 0.7 & 0.4 & 75 \\
Stand. dev. & 163.5 & 0.3 & 43.9 & 2.7 & 1.0 & 49
\end{tabular}

and rivers of the Northern hemisphere (Driscoll et al., 2003; Frey and Smith, 2005; Monteith et al., 2007; Erlandsson et al., 2008; Haaland et al., 2010), including Latvian rivers as well (Klavins et al., 2012). Our data show that despite low data quality and short period of observations (1980-2003), statistically significant upward trends of color values can be found in both rivers (Table 3). However, a closer look at obtained curves indicates also an oscillated character of this process in both cases (Fig. 3). The drivers behind brownification are heavily debated and have been ascribed to hydrological factors (Hongve et al., 2004; Erlandsson et al., 2008), as well as an increase in temperature, changes in land-use and reduced acid deposition (Correll et al., 2001; Freeman et al., 2001; Monteith et al., 2007).

Although it has been difficult to find out a single factor causing brownification, there is an implicit consensus that the direct factor causing this process is the increased concentrations of terrestrially derived organic matter $(\mathrm{OM})$ in the water (Kritzberg and Ekström, 2012).

As we see in Fig. 4, temporal variations of TOC flow in both studied rivers are very similar. Mann-Kendall test results do not show any positive trend in fluxes of organic carbon in the rivers under analysis. While the oscillated charac- 


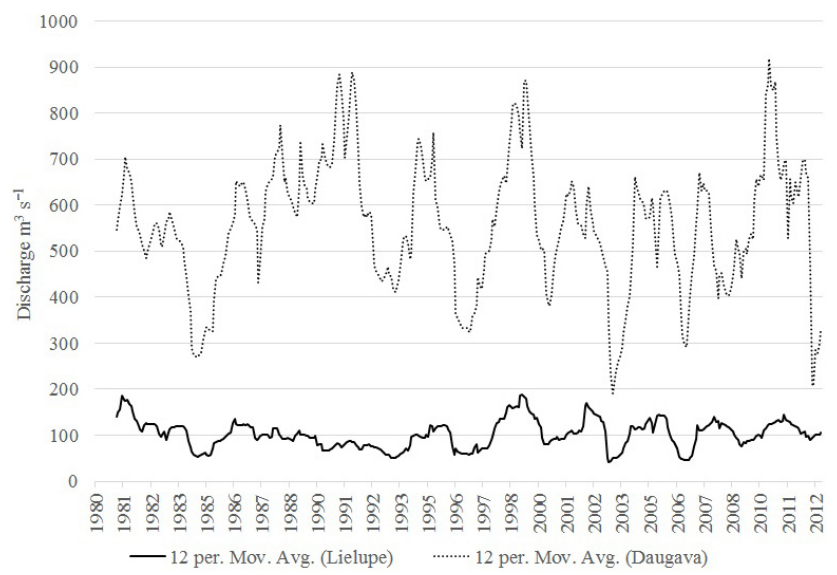

Figure 2. Variation of discharge in studied rivers ( 24 monthly moving average).

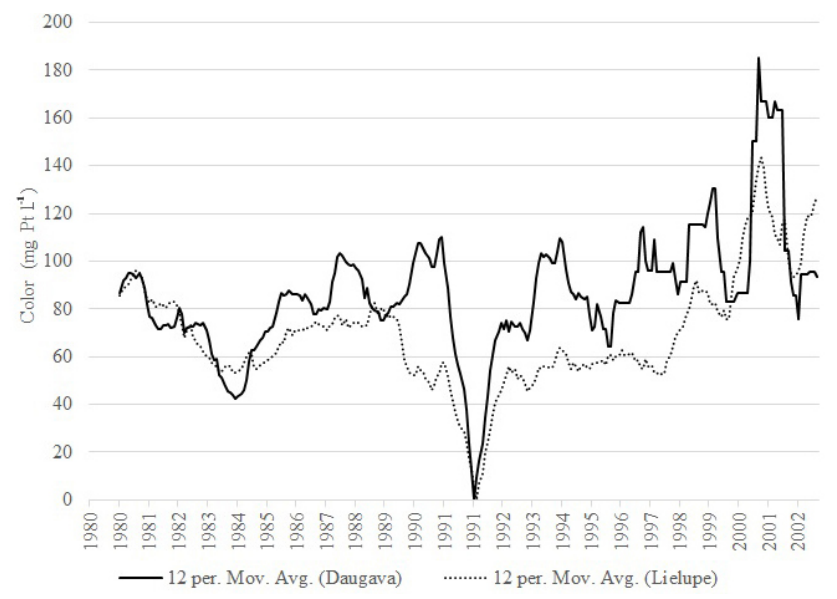

Figure 3. Variation of water color in studied rivers.

ter of data variance is evident, decadal oscillations, as well as oscillations with shorter period (3-6 years) can be observed in both rivers. The character of variation is similar to the character of variation of discharge data, while statistically significant correlation $(r=0.18)$ between TOC concentration and discharge can be observed only in the case of Daugava, but such correlation for the Lielupe river is insignificant (Table 2).

However, it is necessary to admit that the increase in water color cannot be explained only by changes in the quantity and quality of OM, iron also must be mentioned as a potential source of color (Canfield et al., 1984; Kritzberg and Ekström, 2012; Ekström, 2013). Considering low solubility of iron compounds it becomes evident that iron compounds in surface waters exist in form of complexes with OM. Dissolved OM is known to bind to the surface of ferrihydrite and stabilize against aggregation by giving the particle surface a net negative charge (Tipping, 1981), so the flux of organic

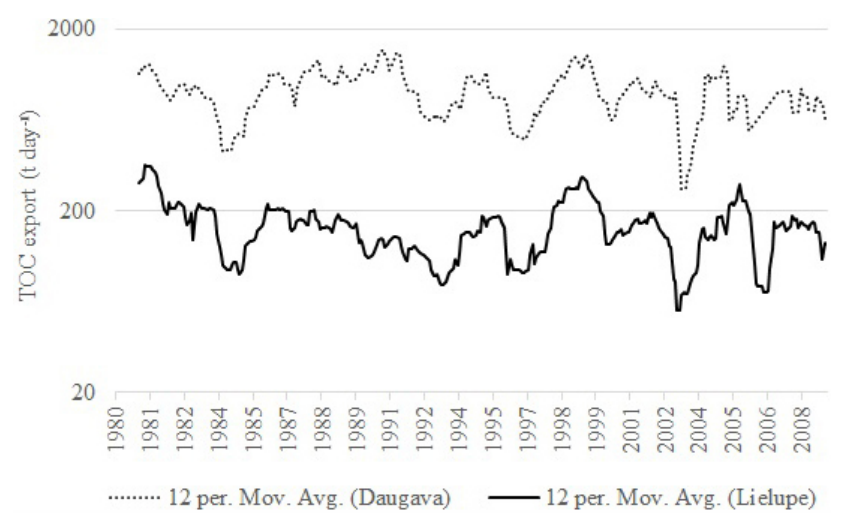

Figure 4. Variation of TOC export in studied rivers.

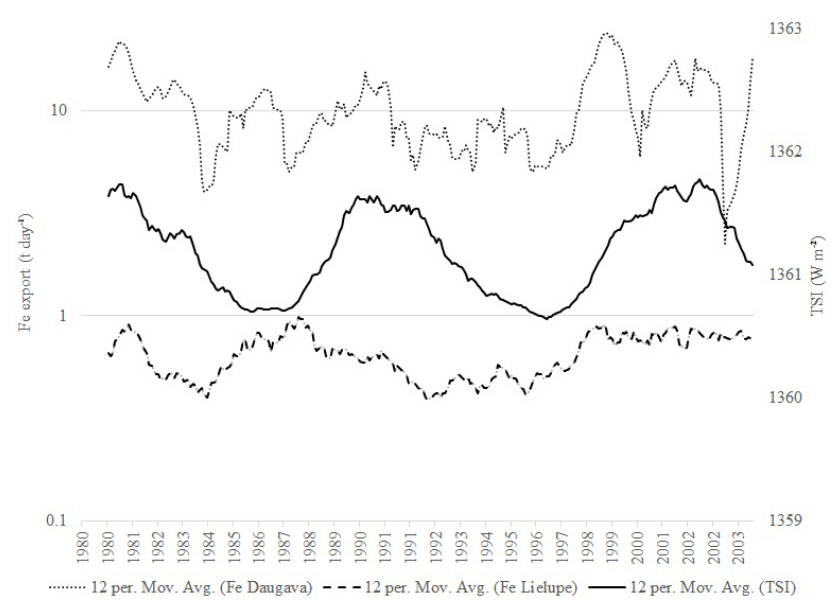

Figure 5. Variation of total iron export in studied rivers and total solar irradiation (TSI).

matter and the flux of iron are strongly connected amongst themselves.

Variation of total iron flux in Lielupe indicates clearly visible decadal oscilations, while period of oscillations in Daugava is shorter (3-6, mainly 4 years). Observed oscillations are highly similar to the cyclic signal of changes in total solar irradiance (TSI) with a periodicity of $\sim 11$ years (Schwabe cycle) between a sunspot minimum and a sunspot maximum, measured instrumentally in the last 3 decades (Frohlich, 2006; Engels and van Geel, 2012) (Fig. 5). Pair regression analysis of total iron fluxes in both catchments in a connection with TSI data shows statistically significant correlations between these values: $R=0.15$ in the case of Lielupe and $R=0.16$ in the case of Daugava. Correlation amongst total iron concentrations and river discharge can be observed in Daugava. In the case of Lielupe these values are not correlative (Table 2).

Differences in both curves can be explained by the difference of iron sources in the studied areas. In the catchment of Daugava as the most significant source of iron, the leaching from soils must be mentioned, as indicated also by a very 
Table 2. Linear correlations between hydro-chemical values and river discharge.

\begin{tabular}{lrr|rc}
\hline & \multicolumn{2}{c|}{ Daugava } & \multicolumn{2}{c}{ Lielupe } \\
\cline { 2 - 5 } & $n$ & $R^{2}$ & $n$ & $R^{2}$ \\
\hline Color & 308 & 0.173 & 310 & 0.088 \\
$\mathrm{~N}-\mathrm{NH}_{4}$ & 368 & 0.047 & 354 & 0.016 \\
$\mathrm{~N}-\mathrm{NO}_{3}$ & 369 & 0.004 & 353 & 0.249 \\
$\mathrm{P}^{-P_{4}}$ & 370 & 0.032 & 362 & 0.030 \\
$\mathrm{Fe}_{\text {tot }}$ & 253 & 0.14 & 274 & 0.014 \\
TOC & 312 & 0.034 & 394 & 0.001 \\
\hline
\end{tabular}

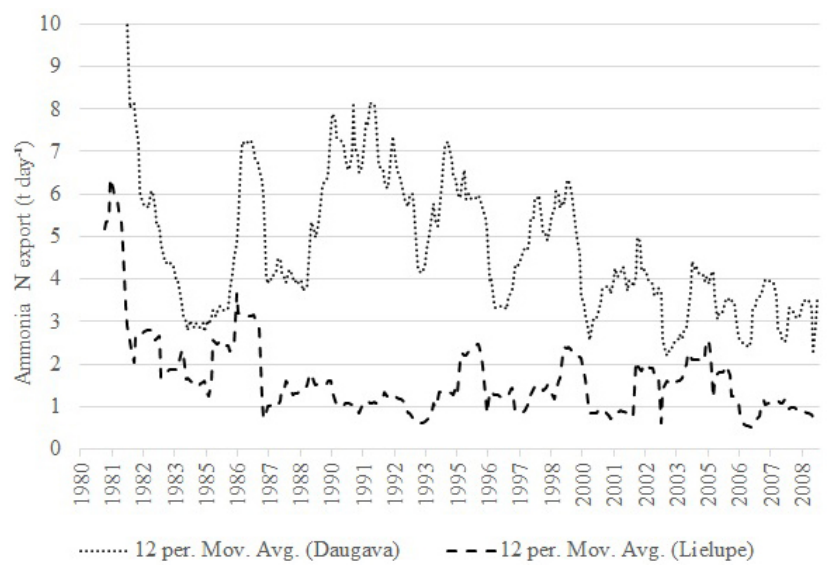

Figure 6. Variation of ammonia nitrogen export in studied rivers.

strong correlation with features of covariation between fluxes of TOC and Total Iron $(R=0.91)$ demonstrating similar sources of both substances (Kritzberg and Ekström, 2012). Meanwhile, in the Lielupe basin the correlation is much less pronounced $(R=0.32)$, indicating difference of sources. It is very likely that the main source of iron in the case of Lielupe is groundwater from Devonian aquifers. It is necessary to add that similar ideas were expressed also by Klavins et al. (2002b) and Delina (2007). So we can make an assumption, that short (3-6 years long) periods of oscillations represent impact of changes in surface and soil runoff, while decadal oscillations represent a hydrodynamic response of deeper underlying aquafers.

The results of Mann Kendall test (Table 3) show that the decrease of nutrient export amounts can be observed in both rivers. These tendencies can be explained by significant reduction of nutrient loads that took place in last decade of XX century, after the collapse of the Soviet economics (Stalnacke, 1996). However, taking into account the oscillational character of nutrient flows, downward trends in Daugava also can be explained with the minimum in cycle with approximately 20 years long period. In this case, upward trends in nutrient export values can be predicted for Daugava catchment, irrespectively to the reduction of loads, in the next few

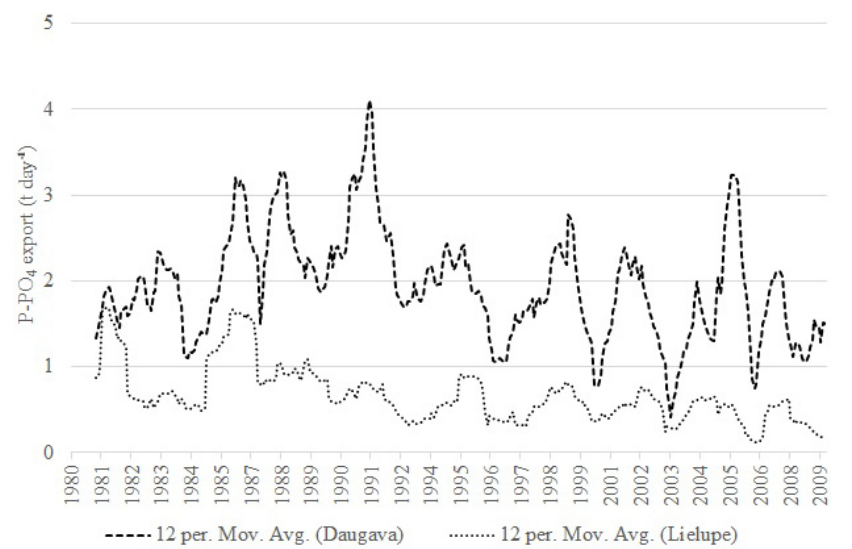

Figure 7. Variation of phosphate phosphorous export in studied rivers.

years. The reduction of phosphorous and ammonia nitrogen exports in Lielupe appears to be more reliable, representing self-purification process of over fertilised agricultural area after sufficient cuts in fertiliser loads.

\section{Conclusions}

Oscillational patterns that can be defined as multiannual pulse of catchment are obviously characteristic of export values variation of the dissolved substances from the studied catchments. The oscillational character of geochemical flows can be explained by impacts of multiple ranges of cyclic natural events driven by changes in solar irradiation, e.g. oscillation of precipitation and river discharge, cyclic oscillations of groundwater aquafers, changes in evaporation intensity. Cyclic character of geochemical fluxes must be taken into account researching geochemical processes, e.g. brownification of waters and self-purification of soils. 30 years long sets of geochemical data are too short for a fully credible linear trend analysis.

We have failed to explain upward trends of color in Daugava and Lielupe rivers by increase of export of OM. Our results show that iron must be mentioned as the very significant factor affecting water color in the studied rivers. The character of brownification in both rivers is oscillational and shows significant connection with solar drivers.

Successful recovery of over-fertilized agricultural area is evident in the case of the Lielupe River. Longer observation period is needed to evaluate self-purification of the Daugava River catchment area. Upward trends of nutrient export values from Daugava catchment are possible in next few years, irrespectively to reduction of loads.

\section{Data availability}

Datasets can be found in the Supplement. 
Table 3. Results of Mann Kendall test.

\begin{tabular}{|c|c|c|c|c|c|c|}
\hline Daugava & TOC exp. & $\mathrm{Fe}_{\text {tot }}$ exp. & $\mathrm{N}-\mathrm{NH}_{4}$ exp. & $\mathrm{N}-\mathrm{NO}_{2}$ exp. & P-PO4 exp. & Color \\
\hline Median value & 650.6 & 7.62 & 3.85 & 26.77 & 1.46 & 83 \\
\hline Kendall statistic & -1385 & -1795 & -10912 & -8362 & -6781 & 2985 \\
\hline$Z$ & -0.75 & -1.36 & -4.63 & -3.53 & -2.85 & 3.18 \\
\hline$P$ & 0.45 & 0.17 & 0 & 0 & 0.004 & 0 \\
\hline $5 \%$ confidence limit & -7.84 & -0.19 & -0.11 & -0.67 & -0.026 & 0.72 \\
\hline $95 \%$ confidence limit & 2.53 & 0.017 & -0.05 & -0.237 & -0.007 & 2.22 \\
\hline Lielupe & TOC export & $\mathrm{Fe}_{\text {tot }}$ export & $\mathrm{N}-\mathrm{NH}_{4}$ export & $\mathrm{N}-\mathrm{NO}_{2}$ export & $\mathrm{P}-\mathrm{PO}_{4}$ export & Color \\
\hline Median value & 93.56 & 0.59 & 0.7 & 9.53 & 0.4 & 72 \\
\hline Kendall statistic & -837 & 2013 & -7555 & -3130 & -13535 & 9103 \\
\hline$Z$ & -0.4 & 1.33 & -3 & -1.4 & -6 & 5.4 \\
\hline$P$ & 0.69 & 0.18 & 0 & 0.16 & 0 & 0 \\
\hline $5 \%$ confidence limit & -0.97 & -0 & -0 & -0.2 & -0 & 1 \\
\hline $95 \%$ confidence limit & 0.59 & 0.008 & -0 & 0.01 & -0 & 1.8 \\
\hline
\end{tabular}

\section{The Supplement related to this article is available online at doi:10.5194/piahs-93-193-2016-supplement.}

\section{References}

Anonymous: Management plan for Lielupe basin district, Latvian Center of Environment, Hydrometeorology and Geology, 2009.

APHA: Standard Methods for the Examination of Water and Wastewater, 18th edition, American Public Health Association, Washington DC, 1992.

Canfield, D. E., Linda, S. B., and Hodgson, L. M: Relations between color and some limnological characteristics of Florida lakes, Water Res. Bull., 20, 323-329, 1984.

Correll, D. L., Jordan, T. E., and Weller, D. E.: Effects of precipitation, air temperature, and land use on organic carbon discharges from Rhode river watersheds, Water Air Soil Poll., 128, 139-159, 2001.

Delina, A.: Quaternary groundwater of Latvia: Disertationes Geologicae Universitas Latviensis Nr. 8, 2007.

Driscoll, C. T., Driscoll, K. M., Roy, K. M., and Mitchell, M. $\mathrm{J}$. :Chemical response of lakes in the Adirondack Region of New York to declines in acidic deposition, Environ. Sci. Technol., 37, 2036-2042, 2003.

Ekström, S.: Brownification of freshwaters-the role of dissolved organic matter and iron, Doctoral dissertation in biology, Lund University, 2013.

Engels, S. and Van Geel, B.: The effects of changing solar activity on climate: contributions from palaeoclimatological studies, Journal of Space Weather and Space Climate, 2, A09, 1-9, 2012.

Erlandsson, M., Buffam, I., Folster, J., Laudon, H., Temnerud, J., Weyhenmeyer, G. A., and Bishop, K.: Thirty-five years of synchrony in the organic matter concentrations of Swedish rivers explained by variation in flow and sulphate, Glob. Change Biol., 14, 1191-1198, 2008.

Freeman, C., Evans, C. D., Monteith, D. T., Reynolds, B., and Fenner, N.: Export of organic carbon from peat soils, Nature, 412, 785-785, 2001
Frey, K. E. and Smith, L. C.: Amplified carbon release from vast West Siberian peatlands by 2100 , Geophys. Res. Lett., 32, 1-4, doi:10.1029/2004GL022025, 2005.

Frohlich, C.: Solar Irradiance Variability since 1978: Revision of the $\{$ PMOD $\}$ Composite during Solar Cycle 21, Space Sci. Rev., 125, 53-65, 2006.

Glazacheva, L.: Long-term trends of the river run-off, air temperature in the Baltic region and atmospheric circulation in the EuroAtlantic sector, in: The factors of regime formation, hydrometeorological conditions and hydrochemical processes in the seas of USSR, Leningrad, Hydrometeorological Agency, 227-241, 1988 (in Russian).

Haaland, S., Hongve, D., Laudon, H., Riise, G., and Vogt, R. D.: Quantifying the Drivers of the Increasing Colored Organic Matter in Boreal Surface Waters, Environ. Sci. Technol., 44, 29752980, 2010.

Henriksen, A., Skjelvale, B. L., Mannio, J., Wilander, A., Harriman, R., Curtis, C., Jensen, J. P., Fjeld, E., and Moiseenko, T.: Northern European lake survey, Ambio, 27, 80-91, 1998.

Hirsch, R. M. and Slack, J. R.: A Nonparametric Trend Test for Seasonal Data with Serial Dependence, Water Resour. Res., 20, 727-732, 1984.

Hongve, D., Riise, G., and Kristiansen, J. F.: Increased colour and organic acid concentrations in Norwegian forest lakes and drinking water - a result of increased precipitation?, Aquat. Sci., 66, 231-238, 2004.

Hounslow, A. W.: Water quality data: analysis and interpretation, Lewis PublBoca Raton, 1995.

Klavins, M., Briede, A., Rodinov, V., Kokorite, I., and Frisk, T.: Long-term changes of the river runoff in Latvia, Boreal Environ. Res., 7, 447-456, 2002a.

Klavins, M., Rodinovs, V., and Kokorite, I.: Chemistry of surface waters in Latvia, Riga, LU, 2002b.

Klavins, M., Kokorite, I., Ansone, L., Eglite, L., Rodinov, V., and Springe, G.: Spectrofluorimetric study of dissolved organic matter in River Salaca (Latvia) basin waters, Knowledge and Management of Aquatic Ecosystems, 404, 1-14, 2012. 
Kritzberg, E. S. and Ekström, S. M.: Increasing iron concentrations in surface waters - a factor behind brownification?, Biogeosciences, 9, 1465-1478, doi:10.5194/bg-9-1465-2012, 2012.

Levina, N., Levins, I., Prols, J., and Straume, J.: Use and monitoring of drinking groundwater resources in Latvia (in Latvian), Geological Service of Latvia, Riga, 1995.

Libiseller, C. and Grimvall, A.: Performance of partial MannKendall test for trend detection in the presence of covariates, Environmetrics, 13, 71-84, 2002.

Monteith, D. T., Stoddard, J. L., Evans, C. D., de Wit, H. A., Forsius, M., Høgasen, T., Wilander, A., Skjelkvale, B. L., Jeffries, D. S., Vuorenmaa, J., Keller, B., Kopacek, J., and Vesely, J.: Dissolved organic carbon trends resulting from changes in atmospheric deposition chemistry, Nature, 450, 537-541, 2007.

Pekarova, P., Miklanek, P., and Pekar, J.: Spatial and temporal runoff oscillation analysis of the main rivers of the world during the 19th-20th centuries, J. Hydrol., 274, 62-79, 2003.
Stålnacke, P.: Nutrient loads to the Baltic Sea, PhD. Thesis, Linköping University: Linköping, 1996.

Standard Methods for Chemical Analysis of Surface Waters: Gidrometeoizdat: Leningrad, 1973 (in Russian).

Statistical yearbook of Latvia: 1996 Central Statistical Bureau of Latvia, Rīga, 1997.

Stumm, W. and Morgan, J. J.: Aquatic chemistry, J. Wiley, NY, 1996.

Tipping, E.: The absorption of aquatic humic substances by iron oxides, Geochim. Cosmochim. Acta, 45, 191-199, 1981.

Tsirkunov, V. V., Nikanorov, A. N., Laznik, M. M., and Dongwei, Z.: Analysis of long-term and seasonal river water quality changes in Latvia, Water Res., 26, 1203-1216, 1992.

Whitehead, P. G., Wilby, R. L., Battarbee, R. W., Kernan, M., and Wade, A. J.: A review of the potential impacts of climate change on surface water quality, Hydrol. Sci., 54, 101-123, 2009. 